\title{
Dampak Pandemi Covid-19 \\ Terhadap Psikologis Masyarakat
}

\author{
Junimiserya Zalukhu \\ Program Studi Ilmu Keperawatan Fakultas Keperawatan \\ Universitas Sumatera Utara, Kota Medan, Indonesia \\ *Email : junimiserya01@ gmail.com
}

\section{Abstract}

The rapid and widespread spread of the COVID-19 pandemic has resulted in significant changes in all aspects of people's lives. The COVID-19 pandemic has caused unrest for all levels of society. this not only affects the physical condition of a person, but also affects the psychological condition of society. Pandemic disease affects people psychologically widely and massively, starting from the way of thinking in understanding information about health and illness, emotional changes (fear, worry, anxiety) and social behavior (avoidance, stigmatization, healthy behavior). In addition, a psychological pandemic, creates prejudice, and outgroup discrimination that has the potential to cause hatred and social conflict.

Keywords : The COVID-19 pandemic, Psychological impact, psychology of society

\section{Abstrak}

Penyebaran Pandemi COVID-19 secara cepat dan luas mengakibat perubahan signifikan pada segala aspek kehidupan masyarakat. Pandemic COVID-19 telah menimbulkan keresahan bagi seluruh lapisan masyarakat. ini tidak hanya memengaruhi kondisi fisik seseorang, tetapi juga memengaruhi kondisi psikologis masyarakat. penyakit pandemi mempengaruhi psikologis orang secara luas dan masif, mulai dari cara berpikir dalam memahami informasi tentang sehat dan sakit, perubahan emosi (takut, khawatir, cemas) dan perilaku sosial (menghindar, stigmasisasi, perilaku sehat). Selain itu, pandemic psikologi, menimbulkan prasangka, dan diskriminasi outgroup yang berpotensi menimbulkan kebencian dan konflik sosial.

Kata Kunci : Pandemi COVID-19, Dampak psikogis, psikologis masyarakat

PENDAHULUAN

Coronavirus Disease 2019

(COVID-19) telah dinyatakan sebagai global pandemic oleh World Health

Organization (WHO) sejak Maret 2020

dan di Indonesia dinyatakan sebagai jenis penyakit yang menimbulkan kedaruratan 
kesehatan masyarakat serta bencana nonalam yang menyebabkan kematian serta menimbulkan kerugian ekonomi yang cukup besar. (Kementerian Kesehatan Republik Indonesia, 2020). Sementara di Indonesia. kasus Covid 19 pertama muncul pada tanggal 2 Maret 2020 dan sampai tanggal 16 Mei 2020 jumlah korban yang terinfeksi telah mencapai 16.496 orang dengan 3083 orang meninggal dan 1076 (https://www.covid19.go.id/). COVID-19, telah menyebar secara luas dan cepat di seluruh dunia termasuk di Indonesia.

Virus Corona merupakan jenis virus baru yang ditemukan pertama kali di Wuhan Cina tahun 2019, kemudian diberi nama Severe Acute Respiratory Syndrom Coronavirus Disease-2019 (COVID-19). Gejala Virus Corona mirip dengan SARS, Jika dilihat dari persentase angka kematian, kasus kematian akibat SARS $(9,6 \%)$ lebih tinggi dibanding COVID-19 (Kurang dari $5 \%$ ). Meskipun demikian jumlah kasus COVID-19 lebih banyak dibanding SARS, COVID19 juga mempunyai penyebaran yang cepat dan luas dibanding SARS. (Agung,2020) Namun yang membedakan adalah mudah menular,transparansi informasi, kekuarangan pasokan bagi tenaga medis, masalah inkubasi virus tidak jelas, karantina bersakala besar, dan "infodemic" yang unik, yaitu banyaknya informasi di media sosial yang menyebabkan pengaruh psikologis pada banyak orang (Dong \& Bouey, 2020). Penyebaran COVID-19 yang cukup luas membawa banyak dampak bagi masyarakat dan terkhusus pasien COVID-19 sendiri. Salah satu dampaknya ialah kehilangan nyawa, penurunan ekonomi, terkendala aktivitas pendidikan, dan sosial. (Garre-Olmo,dkk, 2020), (Suaibatul Aslamiyah.2021)

Kasus kematian akibat COVID-19 dan tindakan isolasi dapat mempengaruhi kesehatan mental masyarakat. Ditemukan bahwa tingginya angka kematian dan perpanjangan isolasi di suatu daerah memicu depresi, kecemasan, rasa takut berlebihan serta perubahan pola tidur masyarakat. Dimana hal ini tidak hanya memperburuk kondisi kesehatan mental namun juga fisik. COVID-19 secara signifikan telah merubah prilaku sosial masyarakat hanya dalam hitungan bulan. Bukan hanya prilaku individu tetapi juga kelompok. Stigma mengenai COVID-19 mulai bermunculan. Mulai dari penolakan sampai diskriminasi terhadap orang dengan COVID-19, seperti para tenaga kesehatan, pasien, kerabat pasien bahkan jenazah orang dengan COVID19.(Suaibatul Aslamiyah.2021) 
METODE

Metode penelitian yang dilakkan adalah literature review. Literature review ini menganalisis jurnal, text book, dan ebook yang relevan dengan pembahasan : Dampak Pandemi Covid-19 Terhadap Psikologis Masyarakat. Jurnal-jurnal yang digunakan adalah jurnal yang diterbitkan dalam rentang tahun 2019-2021.

\section{HASIL}

Berdasarkan review kasus kematian akibat COVID-19 dan tindakan isolasi dapat mempengaruhi kesehatan mental masyarakat. Ditemukan bahwa tingginya angka kematian dan perpanjangan isolasi di suatu daerah memicu depresi, kecemasan, rasa takut berlebihan serta perubahan pola tidur masyarakat. Dimana hal ini tidak hanya memperburuk kondisi kesehatan mental namun juga fisik.7 COVID-19 secara signifikan telah merubah prilaku sosial masyarakat hanya dalam hitungan bulan. Bukan hanya prilaku individu tetapi juga kelompok. Stigma mengenai COVID-19 mulai bermunculan. Mulai dari penolakan sampai diskriminasi terhadap orang dengan COVID-19, seperti para tenaga kesehatan, pasien, kerabat pasien bahkan jenazah orang dengan COVID-19.8 Berdasarkan penelitian-penelitian terdahulu telah ditemukan adanya dampak
COVID-19 terhadap perubahan aspek psikologis. Pada penelitian ini ingin menemukan adanya pembaharuan penemuan selain perubahan kondisi psikologis pada orang yang terinfeksi COVID-19.

\section{PEMBAHASAN}

Taylor (2019) dalam bukunya "The Pandemic of Psychology" menjelaskan bagaimana penyakit pandemi mempengaruhi psikologis orang secara luas dan masif, mulai dari cara berpikir dalam memahami informasi tentang sehat dan sakit, perubahan emosi (takut, khawatir, cemas) dan perilaku sosial (menghindar, stigmasisasi, perilaku sehat). Selain itu, pandemic psikologi, menimbulkan prasangka, dan diskriminasi outgroup-yang berpotensi menimbulkan kebencian dan konflik sosial. Misalkan, penamaan virus corona dengan nama virus Wuhan atau Virus China di awal wabah, telah menimbulkan prasangka, kebencian dan diskriminasi terhadap warga china di beberapa negara, seperti di Autsralia dan Amerika. Pandemi COVID-19, telah mengubah manusia dalam berkomunikasi, dan berinteraksi dengan orang lain.

\section{Dampak Psikologis Pandemi Covid-19}

Pandemi memberikan dampak psikologis yang signifikan pada manusia. Ada tiga elemen dalam pandemi, yaitu 
elemen yang menyebabkan infeksi (virus, bakteri), host (manusia) yang berkaiatan dengan faktor psikologis dalam mengatasi ancaman penyakit tersebut.Terakhir, lingkungan sosial dan fisik yang membantu manusia menghadapi pandemi (Taylor, 2019). Ketiga elemen tersebut saling berinteraksi saling mempengaruhi dalam situasi pandemi. Psikologi pandemi telah mengubah psikologis manusia dalam memahami diri dan relasi sosial.

Peningkatan jumlah kasus semakin meningkat setiap hari mulai jumlah orang ternfeksi dan jumlah kematian, serta dampak pada sosial, dan ekonomi menjadikan kita cenderung lebih waspada dan khawatir. Namun informasi negatif tersebut tidak cukup membuat sebagian besar masyarakat patuh melindungi dirinya, dengan menggunakan masker ketika keluar rumah, karena bias kognisi seperti bias optimistik, yaitu kecenderungan menilai dirinya tidak mengalami risiko terkena penyakit dibandingkan orang lain.

\section{Banyaknya jumlah yang terkena} COVID-19, tidak menyebabkan individu lebih waspada dan protektif pada dirinya. Keyakinan tersebut, sangat beresiko dan berbahaya pada konteks wabah COVID-19 sekarang ini. Bias kognisi sosial mempengaruhi diri individu dalam berpikir dan berperilaku. Bias kognisi dapat disebabkan paparan informasi yang tersedia dalam individu. Paparan informasi yang masif mengenai COVID-19 menyebabkan jumlah ketersediaan informasi mengenai COVID-19 pada individu lebih banyak daripada yang lain. Hasil survei tentang frekuensi mengakses informasi COVID-19 oleh Iskandarsyah \& Yudiana (2020) terhadap 3686 partisipan dari berbagai wilayah Indonesia menunjukkan sebanyak 44,9\% sebanyak < 3 kali, 37\%, 4-5 kali, 9,9\%, 610 kali dan 8,2\% > 10 kali. Ditambah lagi karakter manusia sebagai cognitive misers, yaitu keengganan untuk berpikir secara dalam dengan usaha yang lebih kuat (Pennington, 2000). Akibatnya, potensi terjadi bias heuristik sangat besar. Heuristik adalah proses berpikir (penilaian, pengambilan keputusan) dalam waktu cepat dan seakan tanpa usaha yang berarti (Baron \& Byrne, 2003). Terkadang individu mengandalkan heuristik untuk menuntun mereka pada bahaya yang terungkap dalam situasi yang ambigu. Misalkan, individu dapat menafsirkan kecemasan mereka sendiri atau perilaku mencari keselamatan sebagai indikator ancaman (Blakeya \& Deacon, 2015). Jadi, heuristik dapat mempengaruhi individu dalam berpikir dan berperilaku dalam kondisi pandemi COVID-19. 
Hasil penelitian Wang, dkk (2020) yang melibatkan 1.210 responden dari 194 kota di Cina. Secara total, 53,8\% responden menilai dampak psikologis dari wabah tersebut sedang atau berat; $16,5 \%$ melaporkan gejala depresi sedang hingga berat; $28,8 \%$ melaporkan gejala kecemasan sedang hingga berat; dan $8,1 \%$ melaporkan tingkat stres sedang hingga berat. Hasil penelitian tersebut juga menunjukan bahwa perempauan, lebih rentan terkena stress, cemas dan depresi. Hal senada dengan penelitian Li, dkk (2020) pada 17,865 pengguna aktif Weibo dengan model machine learning. menunjukkan bahwa terjadi peningkatan emosi negatif (cemas, stress) dan penilaian risiko, sementara emosi positif (kebahagiaan, kepuasan hidup) mengalami penurunan.

Respon emosi negatif saat COVID19 tidak hanya terjadi pada orang awam saja, namun kaum pekerja medis pun terkena. Hasil studi di Singapura menunjukkan bahwa COVID-19 berdampak terhadap pekerja medis dan non medis yang bekerja di rumah sakit, seperti kecemasan, stres ,post tautamtic stress disorder ( PTSD) dan depresi (Tan, dkk., 2020).

Sementara studi Huang, dkk (2020) di China menunjukkan bahwa perawat mengalami emosi negatif (cemas dan takut). Sebagai garda terdepan dalam penanganan COVID-19, pekerja medis (dokter, perawat, \& staff) menghadapi situasi yang tidak pasti, penuh risiko,dan tertekan sehingga mudah mengalami gannguan psikologis. COVID-19 memberikan dampak signifikan terhadap kondisi mental pekerja medis. Sebenarnya perubahan emosi, seperti khawatir, cemas dan stres merupakan respon biasa ketika menghadapi situasi pandemi. Hal itu merupakan bentuk mekanisme pertahanan diri atau tanda bahwa ada ancaman yang kita hadapi. Namun, apabila berlebihan, maka akan menganggu kondisi psikologis individu, seperti mengalami depresi.

Data Kementerian ketenagakerjaan mencatat sampai tanggal 10 Apri 2020, sudah ada 1,5 juta yang kehilangan pekerjaan karena COVID-19 (Cnbnindonesia, 2020). Ketika kebutuhan hidup terganggu, maka kondisi ini akan rentan menimbulkan gangguan psikologis lebih hebat dibandingkan COVID-19 itu sendiri. Artinya, pandemi COVID19 secara tidak langsung mempengaruhi kondisi psikologis. Relasi sosial terbatas, tidak dapat berkumpul dengan keluarga (mudik), menimbullkan perasaan kehilangan, kesendirian dan kesepian yang berpotensi memperburuk emosi individu.

Hasil studi Brooks, dkk (200) pada 24 artikel tentang dampak karantina 
wilayah menunjukkan sebagian besar penelitian yang diulas melaporkan efek psikologis negatif termasuk gejala stres pasca-trauma, kebingungan, dan kemarahan. Stresor termasuk durasi karantina yang lebih lama, ketakutan akan infeksi, frustrasi, kebosanan, persediaan yang tidak memadai, informasi yang tidak memadai, kerugian finansial, dan stigma. Situasi psikologis ini yang dirasakan negaranegara yang mengalami karantina atau lockdown, seperti Itali, Spanyol, Rusia, India dan Iran.

\section{Perubahan Perilaku Sosial}

COVID-19 telah mengubah signifikan kehidupan manusia hanya dalam hitungan bulan, perilaku sosial manusia berubah drastis akibat penyesuaian terhadap pandemi COVID19. Perubahan tidak hanya terjadi pada level individu tetapi juga kelompok, organisasi dan perusahaan. Hampir semua aspek terkena, mulai dari pendidikan, ekonomi, politik dan agama. Perubahan itu menimbulkan ketidaknyamanan dan gejolak sosial di masyarakat.

Berdasarkan pengamatan di lapangan dan media online di beberapa wilayah di Indonesia, terdapat perubahan perilaku masyarakat akibat COVID-19. Perubahan itu berasal dari inisiatif sendiri maupun himbauan atau perintah dari otoritas yang berwenang. Misalnya jaga jarak sosial ketika berinteraksi, dan peningkatan solidaritas masyarakat dalam bentuk kepeduliaaan dan perilaku prososial pada masa pandemi. Di sisi lain, pandemik dapat meyebabkan perubahan perilaku berdampak gejolak sosial di tengah masyarakat.Misalkan, penolakan jenazah pasien COVID-19 di beberapa daerah. salah satu yang menjadi masalah pada situasi pandemi adalah stigma (Taylor, 2019; APA, 2020).

Stigma adalah suatu keyakinan negatif dari individu atau kelompok mengenai sesuatu. Stigma dapat berkaitan dengan sesuatu yang tampak dan tak tampak, kontrol dan tidak terkontrol, penampilan, perlaku dan kelompok. Stigma dibentuk sebagai hasil konstruksi oleh masyarakat, dan budaya pada konteks tertentu. (Major, \& O’Brien, 2005). Stigma memiliki dampak signifikan bagi individu dan sosial (Frost, 2011). Stigma dapat merusak kesehatan mental, dan fisik pada penderita penyakit. Stigma dapat berupa penolakan sosial, gosip, kekerasan fisik, dan penolakan layanan. Mengalami stigma dari orang lain dapat menyebabkan peningkatan gejala depresi, dan stres (Earnshaw, 2020).

Ketika seseorang terkena COVID19, maka orang lain akan cenderung memberi stigma negatif ke orang tersebut. 
Bahayanya, pasien menginternalisasi sitgma dari orang lain (Frost, 2011), bahwa dia orang buruk,orangyang salah karena terinfeksi penyakit. Akibatnya akan memperburuk kondisi psikologis pasien. Stigma negatif penyakit COVID-19, membuat orang cenderung melakukan perbuatan yang melanggar norma, yaitu kebohongan atau tidak jujur ketika ditanyakan berkaitan dengan COVID-19/.

\section{Pengaruh Sosial dan Konformitas}

Dalam Psikologi pengaruh sosial merupakan salah satu tema yang banyak dikaji dan diteliti. Pengaruh sosial berkaitan bagaiman individu atau kelompok mempengaruhi atau dipengahi orang lain (individu, kelompok). Dalam konteks situasi pandemi COVID-19, pengaruh sosial menjadi penting khususnya bagi pemerintah untuk mempengaruhi perilaku masyarakat dalam mengurangi penyebaran COVID-19.

Ketika situasi pandemi, keinginan untuk isolasi ditentukan oleh sikap, persepsi norma sosial dan persepsi kontrol perilaku (Zhang, dkk, 2020). Penelitian Wise, dkk (2020) menunjukkan bahwa persepsi risiko tertular dan persepsi dampak COVID-19 (ekonomi, pelayanan kesehatan) meningkat perilaku protektif individu (mencuci tangan, menjaga jarak sosial). Ketakutan dan kecemasan terhadap virus COVID-19 berperan penting dalam mempengaruhi perilaku protektif, seperti mencuci tangan, jarak sosial (Harper, dkk., 2020).

\section{KESIMPULAN}

Penyebaran Pandemi COVID-19

secara cepat dan luas mengakibat perubahan signifikan pada segala aspek kehidupan masyarakat. Pandemi psikologi COVID-19 telah "menyebarkan" ketakutan, kecemasan dan kepanikan secara cepat di seluruh dunia. Ada beberapa dinamika psikologi pandemic COVID-19 yang menjadi perhatian dalam perspektif psikologi sosial, yaitu pengolahan informasi dan bias kognisi, perubahan emosi dan perilaku, serta perngaruh sosial dan konformitas. Dinamika psikologi itu tidak lepas dari interaksi antara karakteristik personal (kepribadian, nilai, pengatahuan), situasi (budaya, norma, agama), dan kebijakan pemerintah dalam menangani pandemi COVID-19. Memahami dinamika sosial psikologis pandemi COVID-19 membantu kita untuk bagiamana berpikir, bersikap dan berperilaku, serta memberikan masukan bagi pemerintah dan pihak-pihak terkait dalam membuat kebijakan penanganan COVID-19 secara akurat. efektif dan komprehensif. 


\section{DAFTAR PUSTAKA}

1. Agung, Ivan Muhammad. (2020). "Memahami Pandemi COVID-19 Dalam Perspektif Psikologi Sosial.” Buletin Ilmiah Psikologi 1 (2) : 68-84. https://doi.org/10.24014/pib.v1i 2.9616.

2. Brooks, K.S. (2020). The Psychological Impact of Quarantine and How to Reduce It: Rapid Review of the Evidence. Lancet, 395, pp. 912-920.

3. Dong L, \& Bouey J. (2020) Public mental health crisis during COVID-19 pandemic, China. Emerging Infection Diseases.7, 2326 https://doi.org/10.3201/eid2607. 200407.

4. Garre-Olmo, Josep, Oriol TurróGarriga, Ruth Martí-Lluch, Lluís Zacarías-Pons, Lia Alves-

Cabratosa, Domènec Serrano-

Sarbosa, Joan Vilalta-Franch, and

Rafel Ramos Blanes. (2020).

"Changes in Lifestyle Resulting from Confinement Due to COVID19 and Depressive Symptomatology: A CrossSectional a PopulationBased Study." Comprehensive Psychiatry, 2020, 1-28. https://doi.org/10.1016/j.comppsyc h. 2020.152214 .

5. Kementerian Kesehatan Republik Indonesia. (2020, April 10). Pedoman Pencegahan dan Penangana Covid 19. hal. https://covid19.go.id/p/protokol/pe doman-pencegahandanpengendalian-coronavirusdiseasecovid-19.

6. Li, S, Wang, Y, Xue, J ,Zhao, N \& Zhu, T 1, (2020). The Impact of COVID-19 Epidemic Declaration on Psychological Consequences: A Study on Active Weibo Users International.Journal of Environment Research and Public Health, , 17, 2032; doi:10.3390/ijerph17062032

7. Pengaruh Covid-19 Terhadap Kesehatan Mental Masyarakat Di Kota Malang Jurnal Ilmu Sosial dan Pendidikan Vol. 4. No. 4 November 2020,550-556

8. Suaibatul Aslamiyah. (2021).

Dampak Covid-19 terhadap Perubahan Psikologis, Sosial dan Ekonomi Pasien Covid-19 di Kelurahan Dendang, Langkat, Sumatera Utara. 1(1), 56-69.

9. Wang, C, Pan, R, Wan, X 1 , Tan, Y, Xu, L 1 ,. Ho,C.S \& Roger C. Ho, R.C(2020). Immediate Psychological Responses and Associated 
Factors during the Initial Stage of the 2019 Coronavirus Disease (COVID-19) Epidemic among the General Population in China., International.Journal of Environment Research and . Public Health, 17, 1729; doi:10.3390/ijerph17051729

10. Wise, T., Zbozinek, T., Michelini, G., Hagan, C. C., \& Mobbs, D. (2020). Changes in risk perception and protective behavior during the first week of the COVID-19 pandemic in the United States. PsyArXiv Preprints. doi: 10.31234/osf.io/dz428. 